\title{
Postconceptional age at the treatment of retinopathy of prematurity in inborn and referred preterm infants from the same institution
}

\author{
Idade pós-concepção no tratamento da retinopatia da prematuridade em pré-termos nascidos \\ e em transferidos para o tratamento em uma mesma instituição
}

João Borges Fortes Filho ${ }^{1}$, Gabriela Unchalo Eckert ${ }^{1}$, Fabiana Borba Valiatti ${ }^{1}$, Paula Gabriela Batista dos Santos ${ }^{1}$, Marlene Coelho da Costa ${ }^{2}$, Renato Solbelmann Procianoy ${ }^{3}$

\begin{abstract}
Purpose: The outcomes of the treatment of retinopathy of prematurity (ROP) seem to be better in inborn patients than in those patients who were referred for ROP treatment. This study aims to investigate the timing of treatment and the outcomes in inborn patients and in patients referred for treatment to the Hospital de Clínicas de Porto Alegre, Brazil.

Methods: An institutional prospective cohort study was conducted from 2002 to 2010 and included in group 1 all inborn preterm neonates treated for retinopathy of prematurity and in group 2 all babies referred for treatment to the same institution. All of the included patients presented birth weight (BW) $\leq 1,500 \mathrm{~g}$ and/or gestational age (GA) $\leq 32$ weeks. Main outcomes were postconceptional age at the treatment and one year follow-up outcomes in both groups. The considered variables were: BW, GA, stage and location of retinopathy of prematurity at treatment.

Results: Group 1 comprised 24 inborn patients. Mean BW and GA at birth were 918 $\pm 232 \mathrm{~g}$ and $28.2 \pm 2.1$ weeks, respectively, and median post-conceptional postconceptional age at treatment was 37 weeks. Group 2 comprised 14 infants transferred for treatment. Mean BW and GA at birth were $885 \pm 188 \mathrm{~g}$ and $28.2 \pm 2.4$ weeks, respectively, and median postconceptional age at treatment was 39 weeks. Mean BW and GA were similar in both groups ( $P=0.654$ and $P=0.949$, respectively), but the difference among the postconceptional age was significant ( $P=0.029)$.

Conclusions: Inborn patients were treated for retinopathy of prematurity during the $37^{\text {th }}$ week of postconceptional age while transferred patients were treated usually, after the $39^{\text {th }}$ week postconceptional age. The worst outcomes observed among referred patients could be partially explained by the delayed time for treatment.
\end{abstract}

Keywords: Infant, very low birth weight; Retinopathy of prematurity/therapy; Gestational age; Hospitals, public; Risk factors; Survival rates

\section{RESUMO}

Objetivos: Os resultados do tratamento da retinopatia da prematuridade (ROP) parecem ser melhores em pacientes nascidos na mesma instituição onde o tratamento foi praticado do que naqueles pacientes transferidos para o tratamento em centros de referência. Este estudo tem como objetivos investigar o momento do tratamento e seus resultados em pacientes nascidos eem pacientes transferidos para o tratamento em uma mesma instituição.

Métodos: Estudo de coorte institucional e prospectivo conduzido de 2002 a 2010 e incluiu no grupo 1 todos os prematuros tratados para a retinopatia da prematuridade nascidos na instituição e no grupo 2 todos os prematuros tratados para a retinopatia da prematuridade transferidos para o tratamento. Todos os pacientes incluídos tinham peso de nascimento (PN) $\leq 1.500$ gramas e/ou idade gestacional (IG) $\leq 32$ semanas. As principais consideradas foram a idade pós-concepção (IPC) por ocasião do tratamento e os resultados do tratamento ao final do $1^{\circ}$ ano de vida dos pacientes nos 2 grupos. As variáveis consideradas foram: peso de nascimento, idade gestacional, estadiamento e localização da retinopatia da prematuridade por ocasião do tratamento.

Resultados: $O$ grupo 1 incluiu 24 prematuros nascidos na instituição. As médias do PN e da IG foram $918 \pm 232$ gramas e 28,2 $\pm 2,1$ semanas, respectivamente. A mediana da idade pós-concepção ao tratamento foi de 37 semanas. O grupo 2 incluiu 14 pacientes transferidos para o tratamento. As médias do PN e da IG foram $885 \pm 188$ gramas e $28,2 \pm 2,4$ semanas, respectivamente. A mediana da idade pós-concepção ao tratamento foi de 39 semanas. As médias dp PN e da IG eram similares nos dois grupos ( $P=0,654$ e $P=0,949$, respectivamente), mas a diferença entre a idade pós-concepção ao tratamento foi significativa entre os 2 grupos $(P=0,029)$.

Conclusões: Os pacientes nascidos na instituição foram tratados para a retinopatia da prematuridade durante a $37^{a}$ semana de idade pós-concepção enquanto os pacientes transferidos foram tratados após a 39ํㅗsemanas de idade pós-concepção em média. Os piores resultados do tratamento assim como do seguimento de um ano observados entre os pacientes do grupo 2 podem ser explicados, em parte, pelo tempo maior decorrido para o tratamento da retinopatia da prematuridade.

Descritores: Recém-nascido de muito baixo peso; Retinopatia da prematuridade/terapia; Idade gestacional; Hospitais públicos; Fatores de risco; Taxa de sobrevida

\section{INTRODUCTION}

Retinopathy of prematurity (ROP) remains one of the leading causes of preventable childhood blindness especially in middle-income countries, where improvements in the perinatal care increased survival rates among very low birth weight (VLBW) preterm neonates ${ }^{(1)}$. Despite the availability of ROP treatment by cryotherapy ${ }^{(2)}$, laser photocoagulation ${ }^{(3)}$ or surgical procedures as pars plicata vitrecto$m y^{(4)}$ and, recently, by the use of intravitreous anti-VEGF therapy ${ }^{(5)}$,
Submitted for publication: May 15, 2010

Accepted for publication: June 27, 2011

Study carried out at the Universidade Federal do Rio Grande do Sul - UFRS.

Physician, Department of Ophthalmology, Medical School, Universidade Federal do Rio Grande do Sul - UFRS - Porto Alegre (RS), Brazil.

Physician, Hospital de Clínicas de Porto Alegre - Porto Alegre (RS), Brazil.

Physician, Departament of Pediatrics, Newborn Section, Medical School, Universidade Federal do Rio Grande do Sul - UFRS - Porto Alegre (RS), Brazil.
Funding: No specific financial support was available for this study.

Disclosure of potential conflicts of interest: J.B.Fortes Filho, None; G.U.Eckert, None; F.B.Valiatti, None; P.G.B.dos Santos, None; M.C.da Costa, None; R.S.Procianoy, None.

Correspondence address: João Borges Fortes Filho. Department of Ophthalmology. Medical School, Universidade Federal do Rio Grande do Sul - Hospital de Clínicas de Porto Alegre. Rua Ramiro Barcelos, 2350 - Porto Alegre (RS) - 90035-003 - Brazil - E-mail: jbfortes@prorop.com.br 
the outcomes for those treated patients remains not as good as desirable ${ }^{(6,7)}$.

In more recent years, the indications for ROP treatment in most of the developed countries are high risk type 1 ROP, defined according to the Early Treatment for ROP Study (ET-ROP), from 2001(8), but in many of the middle-income countries, and especially those in South America, the treatments continue to be performed at threshold ROP, as defined according to the Multicenter Cryotherapy for ROP Study (Cryo ROP), from 1988(2).

We hypothesized that inborn patients were treated sooner than the transferred patients and this factor could have some negative influence at the outcomes for the transferred patients. Our study aims to investigate on this very practical subject for ophthalmologists in charge of performing screening and treatment for ROP.

\section{METHODS}

\section{StUdY DESIGN}

An institutional and prospective cohort study was conducted comparing preterm infants with birth weight (BW) $\leq 1,500 \mathrm{~g}$ and/or gestational age (GA) $\leq 32$ weeks inborn at Hospital de Clínicas de Porto Alegre (HCPA) that needed treatment for ROP with patients transferred to the same institution for treatment of ROP. The study was carried out between October, 2002 and May, 2010.

\section{Setting}

The study was conducted at the neonatal intensive care unit (NICU) of the HCPA in Porto Alegre, Brazil. This is a public level 3university hospital in an urban area with around 3 millions of inhabitants. The NICU has 20 fully equipped intensive care beds and performs around 130 admissions per year considering only VLBW preterm neonates. Routinely screening sessions to detect and treat ROP are performed in more than 95\% of the admitted VLBW. The institutional survival rates for inborn babies under BW $\leq 1,500 \mathrm{~g}$ and BW $\leq 1,000 \mathrm{~g}$ were previously related as $71 \%$ and $41 \%$, respectively ${ }^{(9)}$.

\section{Population AND MEthods}

The patients were included in one of these groups: group 1 comprised all inborn preterm neonates with BW $\leq 1,500 \mathrm{~g}$ and/or gestational age GA $\leq 32$ weeks treated for ROP and group 2 comprised babies with the same BW's and GA's characteristics but referred for treatment to the institution (this BW and GA characteristics are according to the statements of the Brazilian screening criteria to detect and treat ROP, as above mentioned)(10).

All included patients were treated for ROP according to the Cryo $R O P^{(2)}$, and to the Brazilian guidelines to detect and treat $R O P^{(10)}$.

Despite the indications for the treatment of ROP have been changed from threshold ROP (as defined by the Cryo-ROP) to a high risk type $1 \mathrm{ROP}$ (as defined by the ET-ROP) ${ }^{(8)}$, all patients of our study were treated at threshold ROP. The assessments were repeated periodically, according to the Brazilian guidelines for examining and treating $\mathrm{ROP}^{(10)}$ which recommend screening for all babies with BW $\leq 1,500 \mathrm{~g}$ and/or GAd $\leq 32$ weeks and for those babies with risk factors as respiratory distress syndrome, sepsis, intraventricular hemorrhage, babies who needed blood transfusions, and for those being born from multiple gestations. The initial ophthalmological examination was performed between the $4^{\text {th }}$ and $6^{\text {th }}$ weeks of life and were repeated weekly or more frequently according to the findings until full vascularization of the peripheral retina was observed or until 45 weeks of postconceptional age (PCA). The Brazilian guidelines state treatable ROP in ROP zone I, any stage with plus disease, ROP in zone I, stage 3 with no-plus or ROP in zone II, stages 2 or 3 with plus disease or, at least, at threshold $\mathrm{ROP}^{(10,11)}$

ROP was classified according to the International Classification of Retinopathy of Prematurity (stages 1 to 5) ${ }^{(12,13)}$. All of the included patients received outpatient follow-up appointments until completed the first year of life.
All of the patients in both groups were treated by the same ophthalmologist and vitreous-retinal specialist (JBFF). The one year follow-up examinations were performed by the pediatric ophthalmologists (GUE, FBV, PGBS).

The study was conducted from 2002 to 2010 and there were no exclusion criteria.

\section{OUtcomes AND VARIABLes}

Main outcomes were PCA in weeks at treatment (defined as GA + weeks of life) and the treatment outcomes. The ophthalmological examination at the first year of life included search for abnormal visual behavior, strabismus and significant ametropia. We attempted to evaluate binocular visual acuity (VA) in most of the children using Teller's test or Kay's pictures. Refraction was calculated by light retinoscopy under cycloplegia after 30 minutes of two drops of 1\% cyclopentolate in both groups of patients with prescription of corrected lenses if there were myopia, hyperopia or astigmatism of more than 3 dioptries. The considered variables were: BW, GA, stage and location of ROP at treatment, and the one-year refractive status in both groups of patients.

\section{Statistical methods and ethics}

All statistical analyses were conducted using the SSPS software (SPSS ${ }^{\circledR} 16.0$ for Windows ${ }^{\circledR}$; SPSS Inc., Chicago, IL, USA). Independent sample Student's-t test was used to compare both groups of treated patients. Effect size and 95\% confidence interval were calculated for PCA.

The study protocol was approved by the Research Ethics Committee of HCPA (document 04-207) and it is conforms to the provisions of the Declaration of Helsinki in 1995 (as revised in Edinburgh, 2000).

\section{RESULTS}

Group 1 comprised 24 inborn patients. Mean BW and GA were $918 \pm 232 \mathrm{~g}$ and $28 \pm 2.0$ weeks, respectively. Median PCA at treatment was 37 weeks. Group 2 comprised 14 infants referred for ROP treatment. Mean BW and GA were $885 \pm 188 \mathrm{~g}$ and $28 \pm 2.4$ weeks, respectively. Median PCA at treatment was 39 weeks. Mean BW and GA were similar in both groups $(P=0.654$ and $P=0.949$, respectively), but the difference among $P C A$ at treatment in the both groups was significant $(P=0.029)$. The complete data regarding both groups are shown in tables 1 and 2 .

At the one-year follow-up examination, a higher occurrence of strabismus was observed in the group 2 in a total of 4 patients with esotropia (ET) and one patient with exotropia (XT), while in the group 1 only one patient developed XT. Myopia $\geq 3.00$ dioptries was observed in 7 patients in the group 1 and in 6 patients in the group 2. The most complete refractive and anatomical one-year outcomes for the two groups are shown in tables 1 and 2 .

\section{DISCUSSION}

The incidences of any stage of ROP and severe ROP that required treatment in inborn patients in our institution were previously related as $29.9 \%$ and $7.4 \%$, respectively, which is a very low percentage, even for countries with established standards of excellence in perinatal care $^{(14)}$.

Mean BW and GA for the inborn at HCPA treated for ROP in our study were $918 \pm 232 \mathrm{~g}$ and $28 \pm 2.0$ weeks, respectively. These data show a lower BW and GA cohort of treated patients when compared to a similar data $(1,369 \pm 184 \mathrm{~g}$ and $30 \pm 1.8$ weeks) from a recent published article from Hanoi, Vietnam, a country in transitional economy, like Brazil(15). Lower GA and BW have been implicated in the occurrence of ROP in most studies and both are considered the most important risk factors for severe ROP that require treatment in different populations and in different countries ${ }^{(16,17)}$. 
Our study did not show statistical differences regarding BW and GA in both groups (group 1: $918 \mathrm{~g}$ and 28 weeks versus group 2: $885 \mathrm{~g}$ and 28 weeks, $P=0.654$ and $P=0.949$, respectively) but it disclosed that inborn patients were treated for ROP during the $37^{\text {th }}$ week of PCA while referred patients were treated, usually, after the $39^{\text {th }}$ week of $P C A$, being this difference significant $(P=0.029)$.

Table 1. HCPA inborn patients treated for ROP

\begin{tabular}{|c|c|c|c|c|c|c|c|c|}
\hline Case & GA & BW & $\begin{array}{l}\text { Stage of ROP } \\
\text { at treatment }\end{array}$ & $\begin{array}{l}\text { ROP } \\
\text { zone }\end{array}$ & $\begin{array}{c}\text { GA at } \\
\text { treatment }\end{array}$ & Treatment & $\begin{array}{c}\text { Anatomical } \\
\text { results }\end{array}$ & $\begin{array}{l}\text { Refractive } \\
\text { outcomes }\end{array}$ \\
\hline 1 & 25 & 620 & $3+$ & $\|$ & 36 & Laser $1 \times \mathrm{OU}$ & Regression & $-6.00 /-6.00$ \\
\hline 2 & 25 & 755 & $3+$ & $\|$ & 36 & Laser $1 \times \mathrm{OU}$ & Regression & $-6.00 /-5.00$ \\
\hline 3 & 26 & 625 & $3+$ & $\|$ & 36 & Laser $2 \times \mathrm{OU}$ & Regression & $-5.00 /-2.00$ \\
\hline 4 & 26 & 700 & $3+$ & $\|$ & 36 & Laser $1 \times \mathrm{OU}$ & Regression & $+2.00 /+2.00$ \\
\hline 5 & 26 & 710 & $3+$ & $\|$ & 36 & Laser $1 \times$ OU & Regression & $+2.00 /+1.00$ \\
\hline 6 & 26 & 890 & $3+$ & $\|$ & 37 & Laser $1 \times \mathrm{OU}$ & Regression & $-0.50-1.50(180) \mathrm{OU}$ \\
\hline 7 & 26 & 1,080 & $3+$ & $\|$ & 37 & Laser $1 \times \mathrm{OU}$ & Regression & $+3.00 /+3.00$ \\
\hline 8 & 27 & 635 & $3+$ & $\|$ & 36 & Laser $1 \times \mathrm{OU}$ & Regression & $-3.00 /-4.00$ \\
\hline 9 & 27 & 920 & $3+$ & $\|$ & 34 & Laser $1 \times$ OU & Regression & Deceased \\
\hline 10 & 27 & 1,055 & $3+$ & $\|$ & 39 & Laser $1 \times \mathrm{OU}$ & Regression & $+2.00 /+2.00$ \\
\hline 11 & 28 & 730 & $3+$ & $\|$ & 41 & Laser $1 \times \mathrm{OU}$ & Regression & $+2.00 /+1.00$ \\
\hline 12 & 28 & 750 & $3+$ & $\|$ & 38 & Laser $1 \times \mathrm{OU}$ & Regression & $+3.50-1.50(180) \mathrm{OU}$ \\
\hline 13 & 28 & 850 & $3+$ & $\|$ & 37 & Laser $1 \times$ OU & Regression & $-1.00-3.50(180)-1.00-4.00(180)$ \\
\hline 14 & 28 & 1,260 & $3+$ & $\|$ & 37 & Laser $1 \times \mathrm{OU}$ & Regression & $-2.50 / 3.00$ \\
\hline 15 & 29 & 990 & $3+$ & $\|$ & 39 & Laser $1 \times \mathrm{OU}$ & Regression & $-1.50-3.50(180)-2.00-3.50(180)$ \\
\hline 16 & 29 & 1,020 & $3+$ & $\|$ & 41 & Laser $1 \times$ OU & Regression & $+3.00-2.00(180) \mathrm{OU}$ \\
\hline 17 & 30 & 870 & $3+$ & $\|$ & 40 & Laser $1 \times \mathrm{OU}$ & Regression & $-3.00-1.00(180) \mathrm{OU}$ \\
\hline 18 & 30 & 920 & $3+$ & $\|$ & 38 & Laser $2 \times \mathrm{OU}$ & Progression to ROP $4 \mathrm{~A}$ & $-6.00 \mathrm{OU}$ \\
\hline 19 & 30 & 935 & $3+$ & $\|$ & 37 & Laser $1 \times \mathrm{OU}$ & Regression & $-6.00 \mathrm{OU}$ \\
\hline 20 & 30 & 1,500 & $3+$ & $\|$ & 40 & Laser $1 \times$ OU & Regression & -8.00 fixing 1 eye \\
\hline 21 & 31 & 780 & $3+$ & $\|$ & 40 & Laser $2 \times \mathrm{OU}$ & Regression & $+0.50 \mathrm{OU}$ \\
\hline 22 & 31 & 900 & $3+$ & $\|$ & 40 & Laser $1 \times \mathrm{OU}$ & Regression & $+2.00 \mathrm{OU}$ \\
\hline 23 & 31 & 1,230 & $3+$ & $\|$ & 40 & Laser $1 \times \mathrm{OU}$ & Regression & $-2.00-3.50(180) \mathrm{OU}$ \\
\hline 24 & 32 & 1,315 & $3+$ & $\|$ & 41 & Laser $1 \times \mathrm{OU}$ & Regression & $-1.00 /-1.00$ \\
\hline Mean & 28.2 & 918.3 & & & 38.0 & \multirow{5}{*}{$3 \mathrm{pa}$} & & \\
\hline Median & 28.0 & 895.0 & & & 37.0 & & & \\
\hline SD & 2.1 & 231.7 & & & 2.0 & & ents needed $2 x$ laser trea & \\
\hline Min & 25 & 620 & & & 34 & & & \\
\hline Max & 32 & 1,500 & & & 41 & & & \\
\hline
\end{tabular}

$\mathrm{HCPA}=$ Hospital de Clínicas de Porto Alegre; $\mathrm{ROP}=$ retinopathy of prematurity; $\mathrm{BW}=$ birth weight; $\mathrm{GA}=$ gestational age; += plus disease; $\mathrm{SD}=$ standard deviation; $\mathrm{OU}=$ both eyes

Table 2. Patients referred for ROP treatment

\begin{tabular}{|c|c|c|c|c|c|c|c|c|}
\hline Case & GA & BW & $\begin{array}{l}\text { Stage of ROP } \\
\text { at treatment }\end{array}$ & $\begin{array}{l}\text { ROP } \\
\text { zone }\end{array}$ & $\begin{array}{l}\text { GA at } \\
\text { treatment }\end{array}$ & Treatment & $\begin{array}{l}\text { Anatomical } \\
\text { results }\end{array}$ & $\begin{array}{l}\text { Refractive } \\
\text { outcomes }\end{array}$ \\
\hline 1 & 25 & 830 & $3+$ & $\|$ & 42 & Laser $2 \times$ SB OU & Progression to ROP $4 \mathrm{~B}$ OU & NDA \\
\hline 2 & 26 & 640 & $3+$ & $\|$ & 38 & Laser $1 \times \mathrm{OU}$ & Regression & $-3.50-2.00(180) \mathrm{OU}$ \\
\hline 3 & 26 & 705 & $3+$ & $\|$ & 38 & Laser $1 \times \mathrm{OU}$ & Regression & $-2.00(90) \mathrm{OU}$ \\
\hline 4 & 26 & 840 & $3+$ & $\|$ & 38 & Laser $1 \times \mathrm{OU}$ & Regression & $-3.50-2.00(180) \mathrm{OU}$ \\
\hline 5 & 26 & 865 & $3+$ & $\|$ & 40 & Laser $1 \times \mathrm{OU}$ & Progression to ROP $4 \mathrm{~A}$ OS & -2.50 OS fixing 1 eye \\
\hline 6 & 26 & 905 & $3+$ & I- APROP & 37 & Laser $1 \times \mathrm{OU}+$ Avastin 1x OS & Regression & $-5.00 /-5.00$ fixing 1 eye \\
\hline 7 & 28 & 660 & $3+$ & $\|$ & 40 & Laser $1 \times$ OU & Regression & $-4.00 /-3.00$ \\
\hline 8 & 29 & 990 & $3+$ & $\|$ & 39 & laser $1 \times \mathrm{OU}$ & Regression & -2.00 (180) OU fixing 1 eye \\
\hline 9 & 29 & 1,150 & $3+$ & $\|$ & 39 & Laser $2 x+$ SB OU & Progression to ROP $4 \mathrm{~A} \mathrm{OU}$ & $-4.50-3.00$ (180) OS fixing 1 eye \\
\hline 10 & 30 & 725 & $4 \mathrm{~A}$ & $\|$ & 39 & Laser $1 \times \mathrm{OU}$ & Progression toROP 4B OS & $-1.50 /-2.50$ fixing 1 eye \\
\hline 11 & 30 & 865 & $3+$ & $\|$ & 39 & Laser $1 \times \mathrm{OU}$ & Regression & $+1.50-1.00(180) \mathrm{OU}$ \\
\hline 12 & 30 & 890 & $3+$ & $\|$ & 39 & Laser $1 \times \mathrm{OU}$ & Regression & $-3.00 /-4.00$ \\
\hline 13 & 32 & 1,015 & $3+$ & $\|$ & 42 & Laser $1 \times \mathrm{OU}$ & Regression & NDA \\
\hline 14 & 32 & 1,315 & $3+$ & $\|$ & 40 & Laser $1 \times \mathrm{OU}$ & Regression & $-5.00 /-5.00$ \\
\hline Mean & 28.2 & 885.4 & & & 39.3 & & & \\
\hline Median & 28.0 & 865.0 & & & 39.0 & & & \\
\hline SD & 2.4 & 187.7 & & & 1.4 & \multirow{3}{*}{\multicolumn{3}{|c|}{$\begin{array}{l}2 \text { patients needed } 2 \times \text { laser treatment }+ \text { SB } \\
1 \text { patient needed } 1 \times \text { laser }+ \text { Avastin OS }\end{array}$}} \\
\hline Min & 25 & 640 & & & 37 & & & \\
\hline Max & 32 & 1,315 & & & 42 & & & \\
\hline
\end{tabular}

$\mathrm{ROP}=$ retinopathy of prematurity; $\mathrm{BW}=$ birth weight; $\mathrm{GA}=$ gestational age; $+=$ plus disease; $\mathrm{SD}=$ standard deviation; $\mathrm{APROP}=$ aggressive $\mathrm{posterior} \mathrm{ROP} ; \mathrm{SB}=\mathrm{scleral}$ buckle; $\mathrm{OU}=\mathrm{both}$ eyes; OS= left eye; NDA= no data available 
Once both groups had similar BW and GA, the apparent worst outcomes observed among referred patients (Group 2) could be partially explained by the delayed time for treatment. The calculated effect size of the difference in the PCA at treatment among both groups was 0.71 (95\% Cl: 0.02-1.38) which is a moderate effect, but considering the $95 \%$ confidence interval, it can reach to a large effect size.

Among the 24 treated patients at group 1, it was observed that 3 patients needed laser treatment twice to stop ROP progression. At group 2, two patients needed laser twice and also a scleral buckle procedure and one patient needed an antiVEGF intravitreous injection of bevacizumab (Avastin ${ }^{\circledR}$ ) in order to stop ROP progression.

Comparing our data regarding the PCA at treatment for threshold ROP with the recent article published from Vietnam, as previous referenced, we observed that the PCA at treatment for inborn and for referred patients in that study were similar at $36.2 \pm$ 2.3 weeks and $36.3 \pm 2.2$ weeks, respectively, while in our study the PCA for inborn was 37 weeks and the PCA for referred patients was 39 weeks, two weeks later, despite the lower BW and GA found in our patients ${ }^{(15)}$. It is well known, from the results of the Cryo-ROP, that ROP, prethreshold and threshold disease, usually occurs at completed 36 and 37 weeks of PCA, respectively. In this way, the inborn patients in our study were treated for threshold ROP in a median of 37 weeks of PCA, as postulated by the Cryo-ROP. The patients referred for treatment were treated in a median of 39 weeks of PCA, This is at least 2 weeks later that postulated by the Cryo-ROP Study ${ }^{(18,19)}$.

Once both groups of patients in our study did not show differences regarding $B W$ and $G A$, the only difference found in our study was the PCA at treatment. The delayed time for treatment could explain, in part, the worst outcomes observed among the patients referred for treatment.

A very interesting study from Ziakas et al., an audit of ROP screening in the Northern Region of England ${ }^{(20)}$, related that $36 \%$ of the babies who were referred to different institutions developed threshold stage 3 disease. All those babies were under 27 gestational weeks and fewer than $859 \mathrm{~g}$ at birth, smaller babies when compared with the cohort of treated patients related in our study.

There were several patients whose functional outcomes could not be ascertained, especially in group 2 because parents had often moved to a different region or city.

The goal of screening programs is to prevent unfavorable anatomical and functional outcomes from ROP by detecting the more severe stages early enough to allow appropriate laser intervention even if babies need to be transferred to a different institution for ROP treatment.

It is very important to remark the short interval time between the identification of ROP and the appropriate time for successful treatment. Timing is critical because once the vitreous has become involved, or cicatrisation has commenced, retinal ablation by either cryotherapy or laser is ineffective. Treatment should therefore be undertaken as soon as possible, at least within 2-3 days of the identification of threshold disease ${ }^{(2)}$.

Recently, telemedicine for early detection of ROP seems to be a better option than transferring sick premature babies only for expert examination and for treatment in order to save time. Telemedicine in ROP also alleviates the high rate of complications associated with the transfer of very sick preterm patients ${ }^{(21)}$.

\section{CONCLUSIONS}

In this study, inborn patients were treated for ROP during the $37^{\text {th }}$ week of PCA while referred patients were treated, usually, after the $39^{\text {th }}$ week PCA. The worst outcomes observed among referred patients could be partially explained by the delayed time for treatment.

\section{REFERENCES}

1. Gilbert C, Rahi J, Eckstein M, O' Sullivan J, Foster A. Retinopathy of prematurity in middleincome countries. Lancet. 1997:350(9070):12-4.

2. Multicenter trial of cryotherapy for retinopathy of prematurity. Preliminary results. Cryotherapy for Retinopathy of Prematurity Cooperative Group. Arch Ophthalmol. 1988; 106(4):471-9.

3. Good W; Early Treatment for Retinopathy of Prematurity Cooperative Group. Final results of the Early Treatment for Retinopathy of Prematurity (ETROP) randomized trial. Trans Am Ophthalmol Soc. 2004;102:233-48; discussion 248-50.

4. Hartnett ME, Maguluri S, Thompson HW, McColm JR. Comparison of retinal outcomes after scleral buckle or lens-sparing vitrectomy for stage 4 retinopathy of prematurity. Retina. 2004;24(5):753-7.

5. Mintz-Hittner HA, Best LM. Antivascular endothelial growth factor for retinopathy of prematurity. Curr Opin Pediatr. 2009;21(2):182-7.

6. McLoone EM, O'Keefe M, McLoone SF, Lanigan BM. Long term functional and structural outcomes of laser therapy for retinopathy of prematurity. Br J Ophthalmol. 2006;90(6):754-9.

7. McLoone EM, O'Keefe M, McLoone SF, Lanigan BM. Long-term refractive and biometric outcomes following diode laser therapy for retinopathy of prematurity. J AAPOS. 2006; 10(5):454-9.

8. Good WV, Hardy RJ. The multicenter study of Early Treatment for Retinopathy of Prematurity (ETROP). Ophthalmology. 2001;108(6):1013-4.

9. Fortes Filho JB, Eckert GU, Procianoy L, Barros CK, Procianoy RS. Incidence and risk factors for retinopathy of prematurity in very low and in extremely low birth weight infants in a unit-based approach in southern Brazil. Eye (Lond). 2009;23(1):25-30.

10. Zin A, Florencio T, Fortes Filho JB, Nakanami CR, Gianini N, Graziano RM, et al. Brazilian guidelines proposal for screening and treatment of retinopathy of prematurity (ROP). Ara Bras Oftalmol. 2007;70(5):875-83

11. Fortes Filho JB, Eckert GU, Valiatti FB, Dos Santos PG, da Costa MC, Procianoy RS. The influence of gestational age on the dynamic behavior of other risk factors associated with retinopathy of prematurity (ROP). Graefes Arch Clin Exp Ophthalmol. 2010:248(6):893-900.

12. An international classification of retinopathy of prematurity. The Committee for the Classification of Retinopathy of Prematurity. Arch Ophthalmol. 1984;102(8):1130-4.

13. An international classification of retinopathy of prematurity. II. The classification of retinal detachment. The International Committee for the Classification of the Late Stages of Retinopathy of Prematurity. Arch Ophthalmol. 1987;105(7):906-12. Erratum in: Arch Ophthalmol. 1987;105(11):1498.

14. Quinn GE. Retinopathy of prematurity in Brazil: an emerging problem. J Pediatr (Rio J). 2007:83(3):191-3.

15. Carden SM, Luu LN, Nguyen TX, Huynh T, Good W. Retinopathy of prematurity: postmenstrual age at threshold in a transitional economy is similar to that in developed countries. Clin Experiment Ophthalmol. 2008;36(2):159-61.

16. Graziano RM, Leone CR, Cunha SL, Pinheiro AC. [Prevalence of retinopathy of prematurity in very low birth weight infants]. J Pediatr (Rio J). 1997;73(6):377-82. Portuguese. Comment in: J Pediatr (Rio J). 1997;73(6):361-2.

17. Lermann VL, Fortes Filho JB, Procianoy RS. [The prevalence od retinopathy of prematurity in very low birth weight newborn infants]. J Pediatr (Rio J). 2006;82(1):27-32. Portuguese

18. Palmer EA, Flynn JT, Hardy RJ, Phelps DL, Phillips CL, Schaffer DB, et al. Incidence and early course of retinopathy of prematurity. The Cryotherapy for Retinopathy of Prematurity Cooperative Group. Ophthalmology. 1991;98(11):1628-40.

19. Foroozan R, Connolly BP, Tasman WS. Outcomes after laser therapy for threshold retinopathy of prematurity. Ophthalmology. 2001;108(9):1644-6.

20. Ziakas NG, Cottrell DG, Milligan DWA, Pennefather PM, Bamashmus MA, Clarke MP. Regionalisation of retinopathy of prematurity (ROP) screening improves compliance with guidelines: an audit of ROP screening in the Northern Region of England. Brit J Ophthalmol. 2001:85(7):807-10

21. Richter GM, Williams SL, Starren J, Flynn JT, Chiang MF. Telemedicine for retinopathy of prematurity diagnosis: evaluation and challenges. Surv Ophthalmol. 2009;54(6):671-85. 